\title{
Letter to the editor: There is a need to consider all respiratory viruses in suspected mumps cases
}

S J Shepherd (Samantha.Shepherd@ggc.scot.nhs.uk)1, A R MacLean ${ }^{1}$, C Aitken $^{1}$, R N Gunson

1. West of Scotland Specialist Virology Centre, Glasgow, United Kingdom

Citation style for this article:

Shepherd SJ, MacLean AR, Aitken C, Gunson RN. Letter to the editor: There is a need to consider all respiratory viruses in suspected mumps cases. Euro Surveill. 2015;20(33): $\mathrm{pii}=21210$. Available online: $\mathrm{http}: / /$ www.eurosurveillance.org/ViewArticle.aspx?Articleld=21210

Article submitted on 13 August 2015 / published on 20 August 2015

To the editor: The recent paper by Thompson et al. [1] highlighted the detection of influenza $A\left(\mathrm{H}_{3} \mathrm{~N}_{2}\right)$ virus in oral fluids from children with a clinical diagnosis of mumps. They concluded that influenza $\mathrm{A}\left(\mathrm{H}_{3} \mathrm{~N}_{2}\right)$ virus should be considered as part of the differential diagnosis for mumps-like illness, particularly during influenza outbreaks caused by drifted strains. We report here similar findings in our Scottish cohort of patients during the 2014-15 winter season.

Between October 2014 and April 2015, the West of Scotland Specialist Virology Centre in Glasgow received 610 respiratory samples, submitted specifically for mumps virus testing. Mumps outbreaks were known to be occurring within our sample catchment area during that time [2]. The samples submitted consisted of throat swabs ( $n=319)$, buccal/mouth swabs $(n=143)$, gargle samples $(n=132)$, saliva $(n=11)$, unspecified swabs $(n=4)$ and nasopharngeal aspirate $(n=1)$. Of these 610 samples, 250 (41\%) were real-time PCR positive for mumps [3]. The small hydrophobic gene of the mumps virus was sequenced from samples from 19 positive cases and all were genotype G, a prominent genotype in Europe [4].

We re-tested a random subset $(n=137)$ of the mumpsnegative samples for influenza A virus, influenza $B$ virus, parainfluenza 1 to 4 viruses, human metapneumovirus, rhinovirus, adenovirus, coronaviruses (229E, NL63, OC43), respiratory syncitial virus (RSV) and mycoplasma by an in-house real-time PCR [5].

The clinical details for the patients from whom the 137 analysed samples were obtained were as follows: 102 (74\%) were described as having clinical mumps or parotitis, 26 (19\%) had enlarged glands and swollen face/ neck, while the remaining nine had symptoms including an erythematous rash $(n=1)$, orchitis $(n=1)$, pyrexia $(n=1)$ and sore throat $(n=3)$ or were defined by the requesting clinician as a contact of a known mumps case $(n=3)$. The median age for the group tested was 23 years (range: 4 months to 80 years). Vaccination history was unavailable for all patients tested.
Overall, 29 (21\%) of the 137 samples tested were positive for respiratory viruses. A total of 10 samples (7\%) were positive for influenza A virus. Nine were subtyped as $A\left(H_{3} N_{2}\right)$ one was subtyped as $A\left(H_{1} N_{1}\right)$. Eight of the nine $A\left(\mathrm{H}_{3} \mathrm{~N}_{2}\right)$ viruses were sequenced: five were found be subclade $3 \mathrm{C} .2 \mathrm{a}$ (A/Hong Kong/3579/2014) and the remaining three were clade 3 C.3 (A/ Victoria/208/2009). The five patients with 3 C.2a viruses and two of the patients with 3 C. 3 had symptoms described as parotitis or clinical mumps by the requesting clinician. The other patient with a 3 C.3 virus was a contact of a mumps case for whom no clinical details were available. It should be noted that we were unable to sequence one $\mathrm{A}\left(\mathrm{H}_{3} \mathrm{~N}_{2}\right)$ virus (from a patient with a clinical diagnosis of mumps) and the $\mathrm{A}\left(\mathrm{H}_{1} \mathrm{~N}_{1}\right)$ virus (from a patient whose symptoms were parotid swelling) due to low viral load. Two samples were positive for influenza $B$ virus (one patient had enlarged glands and the other had a sore throat) and were found to be B/Yamagata lineage by real-time PCR [6].

Six patients were positive for parainfluenza 3 and all were reported to have had symptoms of parotitis or mumps. Six of eight coronavirus-positive patients also reported symptoms of parotitis or gland swelling. We detected coronavirus 229E $(n=3), N L 63$ ( $n=$ 1) and $\mathrm{OC}_{43}(\mathrm{n}=1)$; the remaining patient had a mixed infection of NL63 and RSV. Another patient with coronavirus $229 \mathrm{E}$ had query mumps and one with pyrexia was found to have NL63 infection. One of two patients positive for rhinovirus had parotitis while the other had testicular swelling. One patient was found to have adenovirus: the clinical presentation was described as enlarged glands.

Our work confirms the findings of Thompson et al., showing that $\mathrm{A}\left(\mathrm{H}_{3} \mathrm{~N}_{2}\right){ }_{3} \mathrm{C} .2 \mathrm{a}$ ( $\mathrm{A} /$ Hong Kong/3579/2014) virus may be found in patients with mumps-like illness. We also highlight that other influenza and non-influenza viruses may also be found in patients with this clinical presentation. This suggests that laboratories and clinicians should consider testing patients who present with mumps-like illness for mumps virus and 
other respiratory pathogens, as relying on clinical diagnosis alone may lead to skewed data for public health teams and surveillance.

\section{Conflict of interest}

None declared.

\section{Authors' contributions}

The study idea was conceived by RNG and CA. Work was performed by SJS and ARM. The letter was written by SJS, ARM and RNG

\section{References}

1. Thompson $\mathrm{Cl}$, Ellis J, Galiano M, Ramsay M, Brown KE, Zambon $M$. Detection of influenza $A\left(\mathrm{H}_{3} \mathrm{~N}_{2}\right)$ virus in children with suspected mumps during winter 2014/15 in England. Euro Surveill. 2015;20(31): $\mathrm{pii}=21203$.

2. Health Protection Scotland (HPS). Measles, mumps, rubella and whooping cough illness and routine childhood vaccine uptake. HPS Weekly Report. 2015;49(2015/27):251-9.

Available from: http://www.hps.scot.nhs.uk/documents/ewr/ pdf2015/1527.pdf

3. Uchida K, Shinohara M, Shimada S, Segawa Y, Doi R, Gotoh $A$, et al. Rapid and sensitive detection of mumps virus RNA directly from clinical samples by real-time PCR. J Med Virol. 2005;75(3):470-4. http://dx.doi.org/10.1002/jmv.20291 PMID:15648065

4. Jin L, Örvell C, Myers R, Rota PA, Nakayama T, Forcic D, et al. Genomic diversity of mumps virus and global distribution of the 12 genotypes. Rev Med Virol. 2015;25(2):85-101. http:// dx.doi.org/10.1002/rmv.1819 PMID:25424978

5. Gunson RN, Carman WF. During the summer 2009 outbreak of "swine flu" in Scotland what respiratory pathogens were diagnosed as $\mathrm{H}_{1} \mathrm{~N}_{1} / 2009$ ? BMC Infect Dis. 2011;11(1):192. http://dx.doi.org/10.1186/1471-2334-11-192 PMID:21752259

6. Biere B, Bauer B, Schweiger B. Differentiation of influenza $B$ virus lineages Yamagata and Victoria by real-time PCR. Clin Microbiol. 2010;48(4):1425-7. http://dx.doi.org/10.1128/ JCM.02116-09 PMID:20107085 